\title{
Documentos
}

\section{AN PEd/ Carta de Caxambu Ao Povo e às Autoridades Constituídas}

Em resposta a todas as iniciativas que determinam, atualmente, $\mathrm{o}$ aviltamento e a deterioração da educação no país, considerando os princípios e compromissos que orientam historicamente sua prática, a ANPEd - Associação Nacional de Pós-graduação e Pesquisa em Educação vem a público:

- denunciar as graves circunstâncias que ameaçam a construção desse projeto coletivo e democrático de educação pública, gratuita e de qualidade;

- reafirmar seu irrestrito compromisso com a instituição do direito à educação, como sentido e como prática;

- rejeitar a submissão da política educacional às orientações de organismos financeiros internacionais;

- conclamar a sociedade brasileira a compartilhar de suas preocupações e reivindicações.

A desmedida centralização na condução dos destinos da educação pública, o sistemático desprezo pelos pronunciamentos dos fóruns e instâncias de deliberação colegiada, bem como o recurso, cada vez mais freqüente, a procedimentos burocráticos impositivos estão entre as tendências de gestão governamental que ferem as dis- posições, os interesses e as mais firmes convicções do coletivo que a ANPEd representa. Assim, a Associação conclama todos aqueles para quem a educação, mais do que um privilégio de poucos, constitui-se em direito de cada um, a denunciar o autoritarismo expresso:

- pelas atuais políticas de avaliação centralizadas nos resultados em todos os níveis de ensino e sua utilização como instrumento do Estado de Regulação Social;

- pelo descomprometimento com a educação infantil e de jovens e adultos;

- pela ausência de políticas concretas para a educação de todos os grupos étnicos constituintes da nação brasileira, assim como dos portadores de necessidades especiais;

- pelas políticas de exclusão relativas à educação no campo;

- pelo desvirtuamento do sentido de autonomia universitária que obriga as IES a buscar fontes alternativas de recursos para garantir a concretização das finalidades de ensino, pesquisa, extensão e práticas culturais.

- pela introdução de um novo modelo de pós-gra- 
duação stricto sensu que induz à descaracterização da formação à pesquisa, mediante a implantação de mestrados profissionalizantes - supostamente capazes de substituir, em alguns casos, o mestrado acadêmico;

- pelo progressivo aligeiramento da formação de professores, em cursos que visam apenas à certificação formal daqueles que se deveriam qualificar para o exercício da profissão;

- pela adoção de procedimentos que, fazendo uso indevido de instrumentos da democracia, previstos constitucionalmente, como as «audiências públicas», acabam por dissimular práticas que legitimam decisões unilaterais e restritivas.

- na concentração de tecnologia em favor de poucos, em detrimento do amplo acesso da população;

Eis porque, reunidos em Caxambu, os associados da ANPEd reafirmam suas históricas posições quanto à exigência de:

- efetiva universalização da educação básica para crianças, jovens e adultos;

- garantia de uma universidade pública, gratuita e de qualidade social;

- condições dignas de trabalho, remuneração, carreira, formação inicial e continuada dos profissionais de todos os níveis e modalidades da educação;

- recursos que possibilitem a garantia de atendimento público e de qualidade das necessidades educacionais em todos seus níveis e modalidades;

- recursos compatíveis com a necessidade de ga- rantir a regularidade, expansão e autonomia nacional da pesquisa e da formação de pesquisadores;

- participação efetiva da sociedade nos processos de concepção, implementação e avaliação da educação pública brasileira;

- processos de avaliação dos programas de pósgraduação que contemplem plenamente o exercício da liberdade acadêmica e científica;

- apoio aos projetos educacionais dos movimentos sociais do campo;

- implementação de mecanismos que divulguem e que incorporem as contribuições que o avanço da pesquisa educacional, em seus diversos campos, vem oferecendo à sociedade brasileira;

- democratização do acesso e do uso criativo e crítico das novas tecnologias, bem como a implementação de políticas de ciência e tecnologia voltadas para o atendimento das necessidades da população brasileira.

Assim, esperam os três mil pesquisadores e pesquisadoras, docentes e estudantes signatários dessa carta expressar sua contribuição ao movimento mais amplo que, delineado em todo o mundo e, em especial, na América Latina, realiza a criação de alternativas democráticas para os países desse continente.

Caxambu, 28 de setembro de 2000, no centenário de nascimento do educador Anísio Teixeira, defensor da democracia educacional brasileira. 